struction, but it requires training to work it. There are $379 \mathrm{I}$ in use in the Post Office, and 1 5,702 among different railway companies. As a railway instrument it is the simplest, cheapest, and most efficient ever devised. The Morse instrument, of which there are 1330 in use in the Post Office and 40,000 on the Continent, records its letters in ink, in dots and dashes on paper tape, and, like the needle and A B C, appeals to the consciousness through the eye; it also indicates the letters of the alphabet by sound, and thus utilises the organ of hearing. Soundreading is gaining ground in England with great rapidity. There are now 2000 sounders in use : in 1869 there were none. In America scarcely any other instrument is used. On the Continent there is scarcely one.

Acoustic reading attains great perfection in Bright's bell instrument, where beats of different sound replace the dot and dash of the Morse alphabet. Sound-reading is more rapid and more accurate than any system of visual signals or permanent record. In fact no record is kept in England, for the paper tape is now destroyed as soon as it has been read. Errors are of course inherent in all systems of telegraphy. A telegraphist cannot see what he writes, or hear what he says, and who is there that does not make mistakes whose eye follows his pen, or whose ear takes in his own words? The Hughes type-instrument, which prints messages in bold Roman characters, is much used on the Continent ; it is, in fact, recognised as the international instrument, but it has had to give way in England to a more rapid system of telegraphy. It is, however, solely used for the Continental circuits by the Submarine Telegraph Company. All long cables are worked by Sir William Thomson's beautiful siphon-recorder.

In ordinary working only one message can be sent in one direction at one time ; but by a simple and ingenious contrivance, by which the neutrality of opposite currents is utilised to convey signals, duplex telegraphy is rendered possible, so that two messages can be sent on the same wire at the same time; and by a still further improvement, where currents of different strength are utilised, four messages are sent on one wire-two simultaneously in opposite directions-at the same time. There are in England 319 duplex and i3 quadruplex circuits at work.

The acme of efficiency in telegraphy is attained in the automatic system, in which manual labour is supplanted by mechanism in transmitting the messages. There are $7 \mathrm{I}$ circuits worked by these instruments, and 224 instruments in use, and a speed of working of $2 \mathrm{co}$ words per minute is easily maintained upon them. When the hand alone is used, from 30 to 40 words fer minute is the maximum rate attained, but by automatic means the limit is scarcely known. Since this system can be duplexed, and in many cases is so, 400 words per minute on one wire are easily sent. By the use of high-speed repeaters, the length of circuit for automatic working is scarcely limited; it would be easy to send roo words per minute to India.

The growth of business since the telegraphs have been acquired by the State is enormous : 126,000 messages per week have grown to an average of 603,000 ; but the mileage of wire has not increased in anything like the same proportion, the excess of traffic having been provided for by the great improvements made in the working capacity of the apparatus. In 1873 , the average number of messages per mile of wire was 147 , it is now 256 . It is in press work that the greatest increase has taken place : 5000 words per day at the time of the Companies have grown to $934, \mathrm{r} 54$ words per day now. 340,966,344 words of press matter were delivered in the year ending March 31,1882 .

The development of railways has necessitated a corresponding increase in the telegraphs required to insure the safety of the travelling public, and while 27,000 miles of wire in England, Scotland, and Wales were used for that purpose in 1869 , at the end of December, I882, the total had increased to 69,000 miles, equipped with 43,176 instruments, against 8678 in 1869 .

The growth of business is equally discernible in the great cable companies. In 1871 the number of messages dealt with by the Eastern Telegraph Company was 186,000 ; in 1881 , it was 720,000 . This growth is equally striking in all civilised countries, and even in Japan $2,223,214$ messages were despatched last year, of which 98 per cent. were in the native tongue. The mode of transacting the trade of the world has been revolutionised, and while wars have been rendered less possible, their conduct has been expedited, and their penalties alleviated.

\section{CENTRAL AND WEST AFRICA 1}

THE brilliant journey of Major Serpa Pinto across Africa from Loanda, by the Zambesi to Natal, must be fresh in the recollection of our readers. The present narrative may be regarded as complementary of the major's exciting story. Captains Capello and Ivens were members of the original expedition along with Major Pinto, and for the first part of the journey the three companions worked together. The object of the expedition, which was organised by the Portuguese (iovernment, was to thoroughly survey the great artery which-a tributary of the Congo-runs from south to north between $17^{\circ}$ and $19^{\circ} \mathrm{E}$. of Greenwich, and is known as the Cuango, as also to determine all the geographical bearings between that river and the west coast, and make a comparative survey of the hydrographical basins of the Congo and Zambesi. The three travellers started from Benguelia in November, 1877 , but had not proceeded far on their journey, when a difference of opinion arose as to the future route of the expedition. Messrs. Capello and Ivens did not feel at liberty to depart from the original letter of their instructions, while the bold Major Pinto conceived that he would be carrying out the spirit of their instructions by making a dash across the continent. We have nothing to do with the quarrels of the travellers; experience proves that in such an expedition there should be one supreme head, and that the best exploring work has often been done by a white traveller single-handed. Major Pinto's presence with the other two was really unnecessary, and it was certainly to the advancement of geographical knowledge that he took an entirely different route. Messis. Capello and Ivens are evidently two pleasant and agreeable gentlemen, though we have some doubts if exploration is exactly the mótier to which they are best adapted. At all events they have written a narrative that contains much pleasant reading, and some additions to our knowledge of the geography and natural history of the limited region which they traversed. Their real work lasted for about two years, during which they traced the Cuango northwards to about $5^{\circ} \mathrm{S}$. lat., when they were compelled to turn back, partly owing to the exhaustion of their supplies, and partly to the arid nature of the country beyond their farthest point. During their journey they crossed innumerable streams, some of them adding their waters to the Cuango and others joining the Cuanza, which discharges into the Atlantic south of Loanda. The sources of the Cunene, Cuanza, and Cuango were visited and determined, and a pretty careful survey of the region all along the route made. The country traversed is mostly mountainous, cut up by innumerable streams and valleys, rich in many parts in vegetation, and even in metals, and having a considerable population clustered in villages, each of which is ruled by its chief. With each of these chiefs much diplomacy had to be used in order that the

\footnotetext{
I "From Benguella to the Territory of Yacca; description of a journey by Alired Elwes, Ph.D. Two vols. (London: Sampson Low and Co.

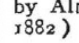


explorers and their followers might obtain provisions and be allowed to pass; but the repetition of the same story of petty troubles and difficulties becomes ere long somewhat tiresome. The habits and dwellings, the implements and weapons, the dispositions and superstitions of the people in this region are pretty much the same as those of the other Bantu tribes with which Pinto, Stanley, Cameron, and other recent explorers bave made us familiar. Among the Ganguella we find considerable

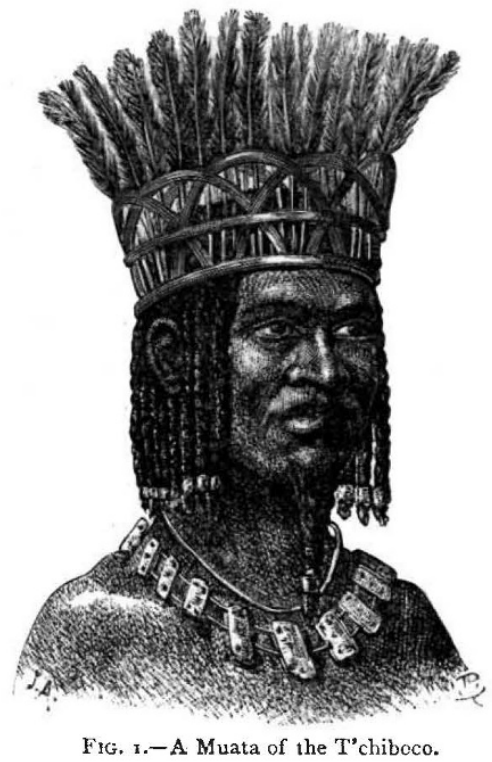

manufactures of iron, while Bihé is rich and fertile, and its inhabitant the greatest native travellers in Africa. In reference to the Bihenos the authors have some curious remarks on the well-known African prefix in its varying forms $m a, b a$, \&c. They seriously lament the ignorance of ethnologists who call the Kafirs "Bantu," a word, they tell us, which simply means "persons." This is in strict analogy with the customs of nearly all peoples, who almost invariably refer to themselves by terms which mean the people, the men, \&c. Bantu has come to have a well-defined ethnological significance, and is not likely to be displaced by the not too well-informed criticisms of our travellers.

Among the people of this region we find the same elaborate methods of dressing the bair, so common in Central and Western Africa, and with which readers of recent African travel must be familiar. We have some interesting details as to the history of some of the leading tribes of the region, from which it is evident that for centuries the various African peoples have been in a state of almost constant migration, that the so-called tates are exceedingly unstable, and that even here it ould be hazardous to regard any one race as unmixed.

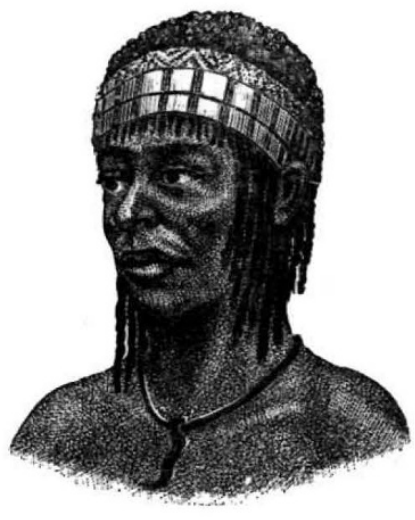

FIG. 2.-Woman of Cangombe

Ve give here two types: Fig. I, a Muata, or ruler, of the "chiboco ; and Fig. 2, a woman of Cangombe.

The sources of the Cuango were found at a height of $475^{6}$ feet, at about $11 \frac{1}{2}^{\circ} \mathrm{S}$., and a little east of $19^{\circ} \mathrm{E}$., in one of the most extraordinary watersheds to be met with anywhere. It is thus described :-

"An extensive tract of land, all hill and dale, marks this culminating point, a sort of St. Gothard of the African waters. On the north, running through a narrow and tortuous valley, appeared the Cuango, which, shortly after its birth, flows at the foot of the plantations of manioc and massambala, growing abundantly upon the slopes, and at that time filled with girls and women engaged in hoeing and otker field labours. A bluish

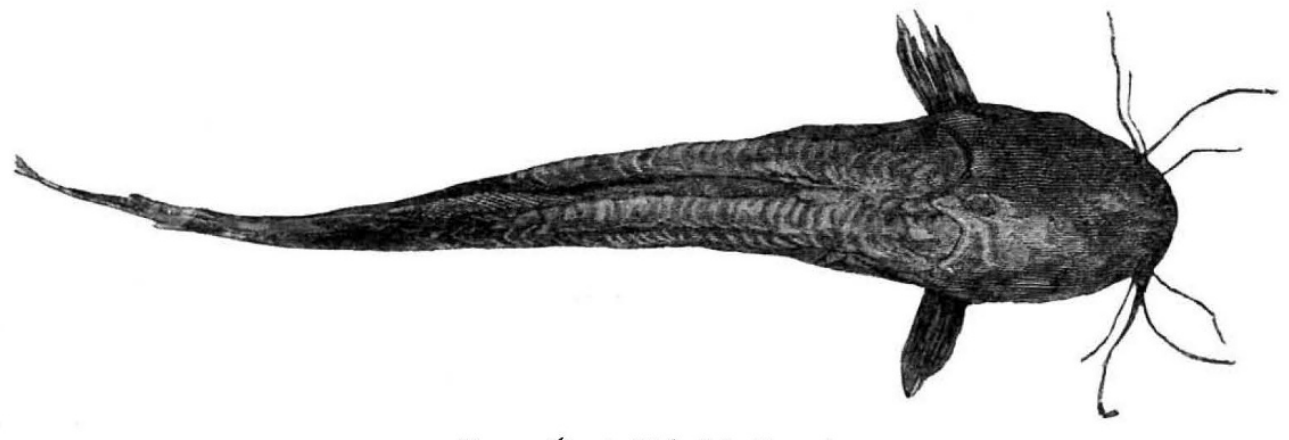

F1G. 3.- Ébande (Fish of the Cuango).

streak of land was visible in a south-west direction, and on the western slope, in Canica, appeared the sources of the Caùeu rivulet, which constitutes the modest commencement of the great Cassai. To the north-east stretched out the T'chibungo range, on whose eastern slope were visible the sources of the T'chipaca at about twenty-five miles from the point of observation, and whose latitude was $11^{\circ} 27^{\prime}$ and longitude $19^{\circ} I I^{\prime} 30^{\prime \prime}$. Finally, the eye took in at various distances, approximately determined by the compass, an infinity of springheads, the sources of various affluents of the T'chipaca, the Cuango, the Cassai, the Lume, and the Loando, which, glittering in all directions, poured their everincreasing waters to the Congo-Zaire, the Cuanza and the Zambese, till they were lost to sight in the valleys and ravines, where a denser vegetation still hinted at their sinuous course. The aspect of the country was magnificent. In the east, extended as far as the eye could reach, the rich green valley of the upper Cassai, clothed with numerous senzalas of ma-quioco and ma-cosa, indicated by the white patches of manioc flour spread to dry upon the luandos or mats of the mabu." 
Speaking again of the same remarkable region, the writers say :--

"In a lofty position - the mean altitude being I $_{53} \mathrm{I}$ feet - the intense heat of the tropics is far from predominant, and the breeze which is stirring during a part of the year renders the climate soft and salubrious to the European. Standing upon a granitic plateau, the region may properly be described as the Mother of the African Waters, are important. There are Apocinaceas, or india-rubber trees; Burseraceas, which yield aromatic resins such as the Eleni; Herminieras, used in the building of canoes; Rubiacias, or teak, mixed with Erythrinas, producing

,

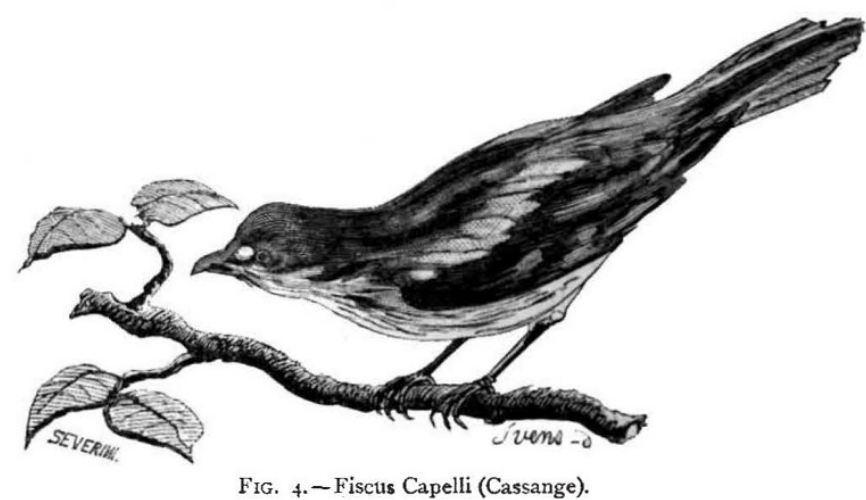

a veritable hydrographic centre whence issue, through deep gullies, the streams that flow to the two great oceans by the channels of the Congo-Zaire, the Cuanza, and the Zambese. Its mineral wealth is considerabie, abounding chiefly in oligist iron; native copper exists more to the eastward, where, if we may rely upon the reports of the natives, the lodes are easily worked. The vegetable products, more especially upon the banks of the great rivers,

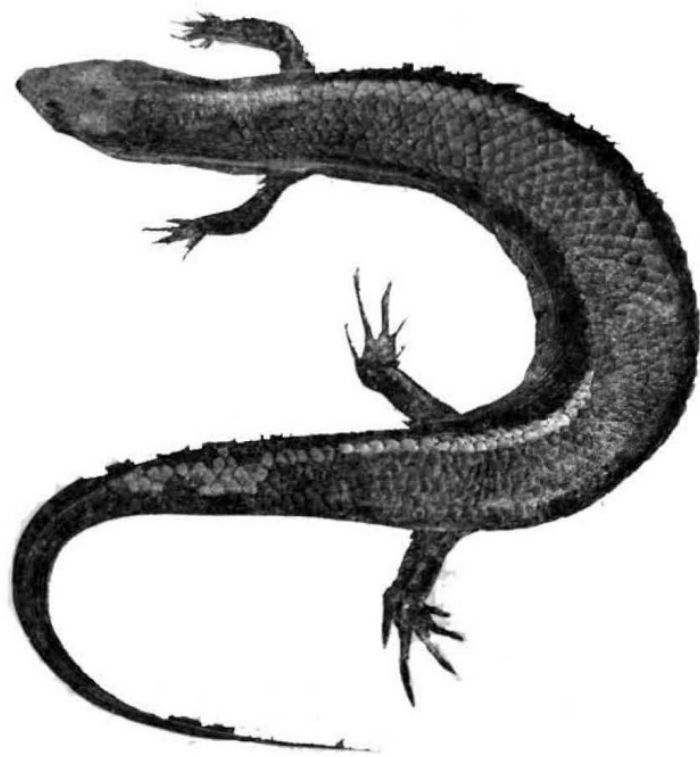

FIG. 5. -Euprepes Ivensi (new species), River Cuanza.

cork ; several Euphorbias, acacias used for dyeing purposes; Typhas, and a species of Borassus; grasses of various kinds, such as the panicum and andropogon, the

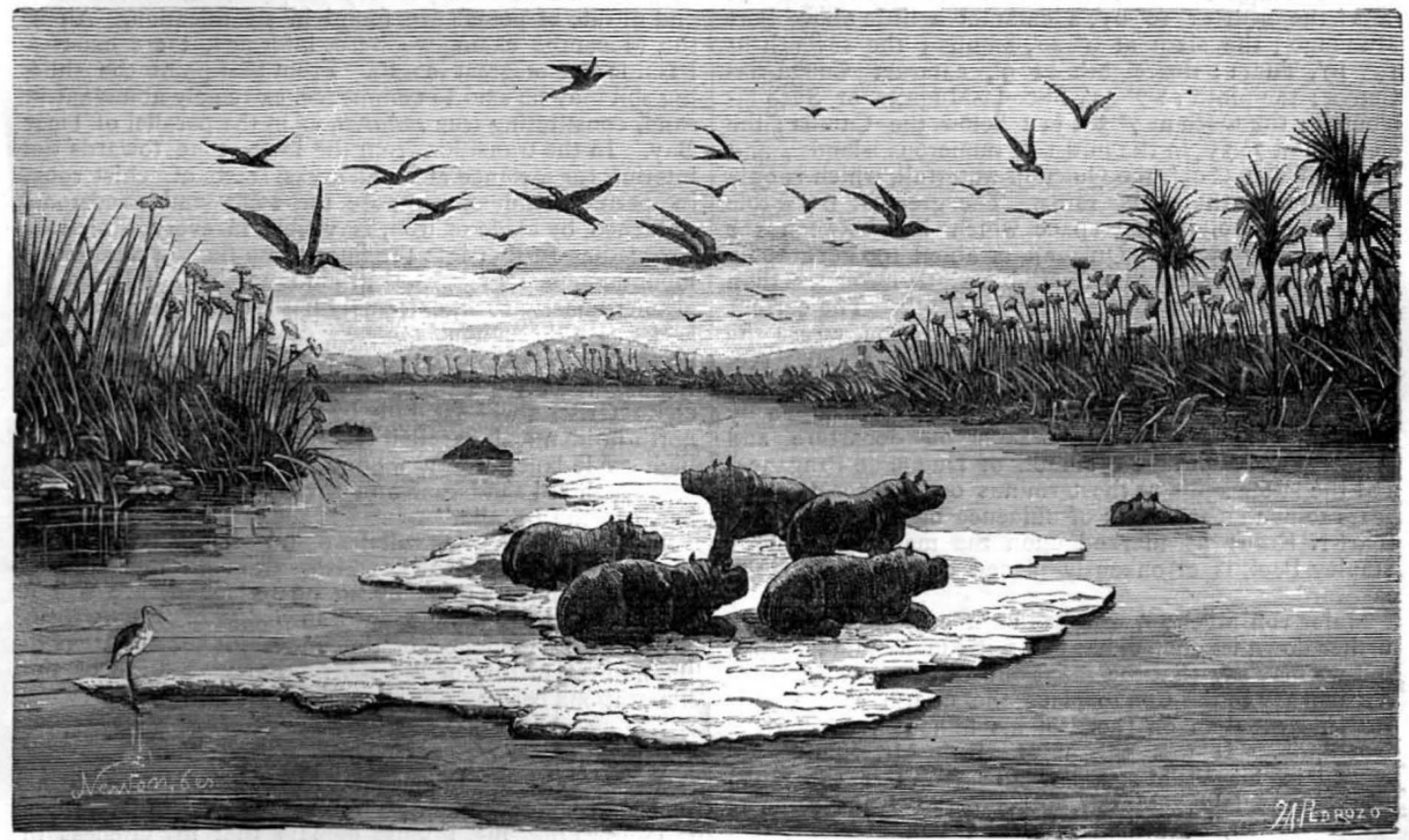

FIG. 6.-The Cuango in Yacca.

penusetum, both smooth and barbed (massango), hemp, | T'chibozo are distinguishable the fungo, not unlike a and a large number of Convolvulaceas; all these we plum, but less pulpy and more sour, which grows upon a ourselves saw. Among the variety of wild fruits of medium-sized tree; the macoll $\pi$, of the granular species, 
having the shape and size of an orange, but resembling internally the American muruenia, that produces purgative effects when taken in large doses; the tongo, similar in form and dimensions to the white plum; and the tundo, almost equal to a cherry in taste, and having black seeds. The abundance of wax is really remarkable, and towards the south and south-east it constitutes an important branch of industry."

At this point the two travellers separated in order to proceed northwards on different sides of the Cuango, and met again at Cassange, where they fell in with Dr. Max Buchner, on his way to the great Muata Yanvo. Of this famous potentate Messrs. Capello and Ivens give a fancy portrait, which contrasts markedly with that taken from the original by the German explorers who have recently done so much for a scientific knowledge of the region through which the route of the Portuguese travellers lay. Cassange may be regarded as the furthest Portuguese outpost, and a busy centre it is.

Yacca, the furtheit limit of the expedition, was reached in May, I879, and although innumerable small lakes and many streams had been passed, the region beyond was found to be an arid desert, brooded over by "the silence of the grave." Here is a summary of the travellers' observations on the course of the Cuango from its source to the limit of their journey, about I 40 miles from where the river discharges into the Congo:-

"From parallel $1 \mathrm{I}^{\circ} 3 \mathrm{O}^{\circ}$, approximately, where its sources are to be found, up to $5^{\circ} 05^{\prime}$ at the Quicunji cascade, the river has a sinuous course of 580 geographic miles, and a total fall between its extreme points of about 3 feet 4 inches per mile. Rocks, stones, rapids, and cataracts interrupt the stream, and twelve of the points at which they do so are known to us, namely, the first at parallel $10^{\circ} 17^{\prime}$, to the east of Muene-songo; the second at $10^{\circ} 25^{\prime}$, near the Camba rivulet; the third at $10^{\circ} 08^{\prime}$, Caxita rocks; the fourth at $10^{\circ} 05^{\prime}$, the Louisa falls; the fifth at $10^{\circ} 05^{\prime}$, a cataract a little above Port Muhungo; the sixth at $9^{\circ} 20^{\prime}$, Zamba ; the seventh at I9 $9^{\circ} 9^{\prime}$, Tuaza; the eighth at $9^{\circ}$, cataract Cunga-riaCunga; the ninth at $7^{\circ} 42^{\prime}$, Suco-ia-Muquita or Suco-ian'bundi; the tenth at $7^{\circ} 38^{\prime}$, just below the Camba; the eleventh at $7^{\circ} 35^{\prime}$, in the midst of numerous islands; and the twelfth at $5^{\circ} 05^{\prime}$, the Quicunji waterfall, which is only passable after the heavy rains. The greatest navigable tract, therefore, is that space which lies between the cataract at $7^{\circ} 35^{\prime}$ and Quicunji, or about 190 geographic miles. The river there is of variable width, never less than $76 \frac{1}{2}$ yards, and from 5 to 20 feet in depth. The current loses a little of its speed in the upper section, where the stream in the summer season has a fall of about 3 feet 2 inches per mile. We think it well to mention that our longitudes being strictly correct, as the record, partly chronometric, was compared both on departure and arrival at the Portuguese station of Duque de Bragança, and the latter again at the terminus on the coast, it appears to us that the point of affluence of the Cuango (or Ibari-N'Kutu) as marked upon the maps, just above Stanley Pool, is erroneously placed considerably to the eastward."

Major von Mechow, who has been exploring the river urther down its course, has found it equally unnavigable, and we may say that the maps illustrating Mr. Stanley's last journey to the Congo place the mouth of the river further west than on those of his famous trans-African expedition. It was this river which $\mathrm{Mr}$. Stanley as. cended in his little steamer, and found it expanding into a broad lake. Messrs. Capello and Ivens came to the conclusion, confirmed by Major von Mechow, that no such lake as Aquilonda exists in this quarter. The travellers returned by a somewhat different route, staying for some time at Pungo N'Dongo, with its famous rocks, and reaching Loanda in October, 1879.

The work abounds with illustrations of the country and the people, many of them devoted to natural history. On the animal and plant life of the district traversed there are many valuable notes, and in the appendix will be found, besides tables of geographical observations anheights above sea-level, lists of additions to the fauna and flora, tables of African dialects, and a N'Bunda Vocabulary. There is a good summary of the general results in the concluding chapter, in which the authors have the following observations on the geology of the continent:-

"The physical configuration of the African continent, and more especially of the portion south of the equator, is nowadays too well known to require minute description. It may be summed up in these few words: a depressed central basin surrounded by a vast circle of high land, gradually descending to the sea, and rent by deep ravines, through which rush huge watercourses, engendered in the interior, till they overflow and seek the lower level fronting the ocean. From a very general geological point of view we may define the regions running from the littoral to the interior in the following order, viz. limestone, sandstone, and granite. But on going more minutely into the subject we shall find that these distinctions are not very exact; inasmuch as the component parts frequently run into each other and change places, while precise lines of demarcation are wanting. The geological formation on the western coast at the points observed by us between Loanda and Mossamedes, and even further to the north, exhibits generally near the sea a belt of tertiary deposits, with abundant masses of sulphate of lime and sandstone, from which they are separated by beds of white chalk alternating with primary rocks, for the most part gneiss, abounding in quartz, mica, hornblende, granite, and granulated porphyry. Towards the south large tracts of feldspar become visible. At Mossamedes whole mountains are composed of sulphate of lime; while carbonate of lime, accumulated in shells, is very frequent. Both rock-salt and nitrate of potash are found in stratification. Along the Mocambe chain, we were informed, there exists a basaltic line of great length. From that point the shifting soil may be said to commence, extremely abundant in sand, constituting true saharas, as in the parallel of Tiger Bay. In the transition from the lower zone towards the interior, for instance at Dondo, vast tracts of schist rock, in perfect laminæ, compose the soil; and sandstone reddened by oxide of iron, is visible in every direction. Proceeding further into the interior we find, in a perfectly mountainous region, the ground to be composed of granite-quartzy rock, extremely hard and compact; this is the case throughout the belt crossed on the way and up to Pungo N'Dongo, the surface soil being formed by the disintegration of the granite itself. These geological characteristics will naturally be repeated to the south and north in identical parallel regions, with variations in the high table-land, where we meet occasionally with hard and tough red sandstone and rock; of feldspar as in the basin of the Lucalla."

In the same chapter will be found abundant notes on the various tribes visited, which, although the authors' ethnology appears to us by no means sound, are still a valuable contribution to a knowledge of the African peoples. As evidence of the important contributions to the natural history of West Africa, we give a few of the illustrations bearing on the subject.

\section{ON THE AURORA BOREALIS}

HAVING been requested by this journal to give an account of my latest researches into the nature of the aurora borealis, I must explain that my lateness in

I In reference to the present interesting communication from Herr Sophus Tromholt, from his station in Ultima Thule, we ought to point out that Herr as regards the nature of the aurJra made by Prof. Lemström at the Finnish station of Sodankylä during December appeared in NATURE, vol. xxvii. p. $3^{22}$. 